\title{
The internal geology and emplacement history of the Renard 2 kimberlite, Superior Province, Canada
}

\author{
C.E. Fitzgerald ${ }^{1}$, C.M. Hetman ${ }^{2}$, I.M. Lepine ${ }^{1}$, D.S. Skelton ${ }^{1}$ and T.E. McCandless ${ }^{1}$ \\ 1 Stornoway Diamonds Corporation 116-980 West 1st St., North Vancouver, BC, V7P 3N4 \\ 2 Mineral Services Canada, 205-930 Harbourside Dr., North Vancouver, BC, V7P 3S7
}

\section{Introduction}

The Renard 2 kimberlite is the largest of 9 pipes in the Renard cluster located in the eastern James Bay region of Quebec, Canada. It was emplaced into the Archean trondjhemite tonalite gneiss terrane of the eastern Superior province at approximately $640.5 \pm 2.8 \mathrm{Ma}$. An undetermined amount of erosion has since occurred, with the present surface expression of the pipe estimated as 0.75 ha. This kimberlite is steep-sided diatreme with minor irregularities in the external shape. The dominant pipe infill is a massive volcaniclastic kimberlite (MVK), characterized by a high proportion of granitoid country rock xenoliths that is classified as a tuffisitic kimberlite breccia (TKB). The second dominant pipe infill is a texturally complex, less diluted coherent kimberlite. In addition to the main pipe infills, a significant number of hypabyssal kimberlite (HK) dykes and irregular intrusions are found throughout the body. Surrounding the main conduit are significant zones of extensively brecciated country rock (+/- kimberlite) of variable width referred to as marginal breccias. Evaluation work undertaken on Renard 2 includes extensive core and reverse circulation drilling and the collection of an underground bulk sample. Core logging, underground mapping, petrographic studies, xenolith abundance measurements, and diamond analysis have been undertaken and these investigations have revealed a simple internal geology model. Geological features displayed by Renard 2 are similar to those described from Class 1 kimberlites of the Kimberley area of South Africa (Clement, 1982), the Gahcho Kué cluster of Canada (Hetman et al., 2004) and the Pimenta Bueno kimberlite field of Brazil (Masun and Scott Smith, 2006).

\section{Internal Geology of Renard 2}

Renard 2 (Fig.1) is an elliptical, north trending, steep sided, diatreme that tapers with depth and has been drilled to $564 \mathrm{~m}$ below the present surface. There are two main phases of kimberlite that infill the pipe referred to as the Blue and the Brown kimberlites. These exhibit contrasting primary textures, olivine populations, xenolith abundances and diamond contents.

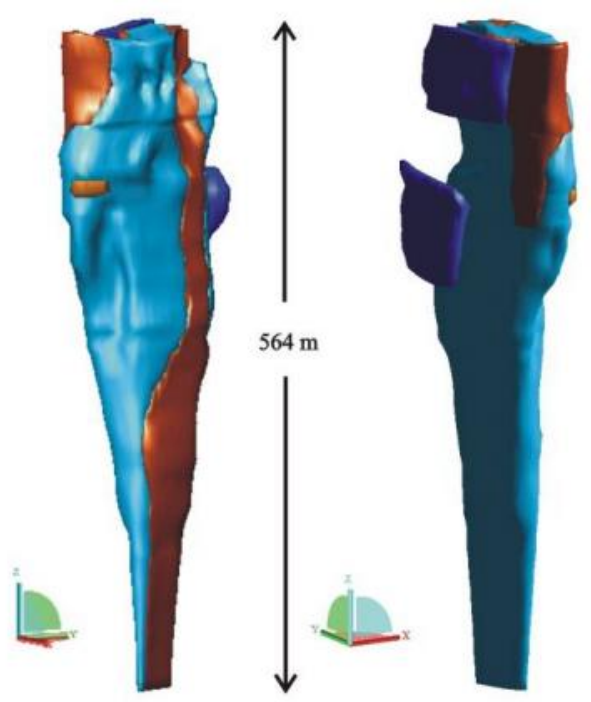

Figure 1: Three-dimensional representation of the Renard 2 kimberlite showing the distribution of the Blue and Brown kimberlites. Irregular coherent kimberlite is shown adjacent to the main body in dark blue.

The Blue kimberlite (Fig. 1, 2a) is volumetrically the most significant phase present within the diatreme and is described as an extensively altered, massive MVK and classified as a TKB (sensu stricto, Clement 1982 and Hetman 2008). Completely pseudomorphed, subhedral olivine macrocrysts and subhedral to euhedral olivine phenocrysts are set within an interclast matrix comprised of serpentine, clinopyroxene microlites and clay minerals. The olivine morphology and distribution is similar to that of a hypabyssal kimberlite; however, the total abundance is lower due to the high proportion of country rock. The kimberlite is poorly-sorted, loosely-packed and less commonly clast supported, with abundant pelletal shaped juvenile clasts that include both uncored and thin skinned varieties. Complex and/or mineralogically diverse juvenile clasts have not been identified. Groundmass minerals present within the selvages include phlogopite, perovskite and spinel. Mantle derived indicator minerals are extremely rare. Underground exposures show localized vertical fabrics (on a metre scale) generally associated with geologic contacts, which are highlighted by changes in xenolith size and abundance. Xenolith abundance is variable and often elevated near pipe margins. The xenolith population is dominated by locally derived granitoid with lesser 
gneissic xenoliths that are typically fresh to moderately altered, angular to sub-rounded and vary in abundance from 30 to $70 \%$.

The Brown kimberlite (Fig. 1, 2b, 2c) is a moderately altered, texturally variable, massive coherent rock that displays localized transitional textures. Subtle fabrics are present in the underground exposures and these consist of vertically aligned country rock clasts and a single localized subhorizontal fabric defined by country rock xenoliths. The olivine population consists of extensively altered to less common partially fresh, subhedral olivine macrocrysts and subhedral to euhedral olivine phenocrysts set with a variably crystallized, inhomogeneous crystalline groundmass. The olivine morphology and distribution is similar to that of a hypabyssal kimberlite. Mantle derived indicators are extremely rare. Primary groundmass minerals include phlogopite, perovskite and spinel. Clinopyroxene can be abundant within the groundmass; however, these are associated with areas of digested granitic material and are considered secondary. Country rock xenoliths include both granitoid and gneiss; however, the latter predominate. These are subangular to rounded and show variable reaction to the host kimberlite that includes complete digestion of xenoliths.
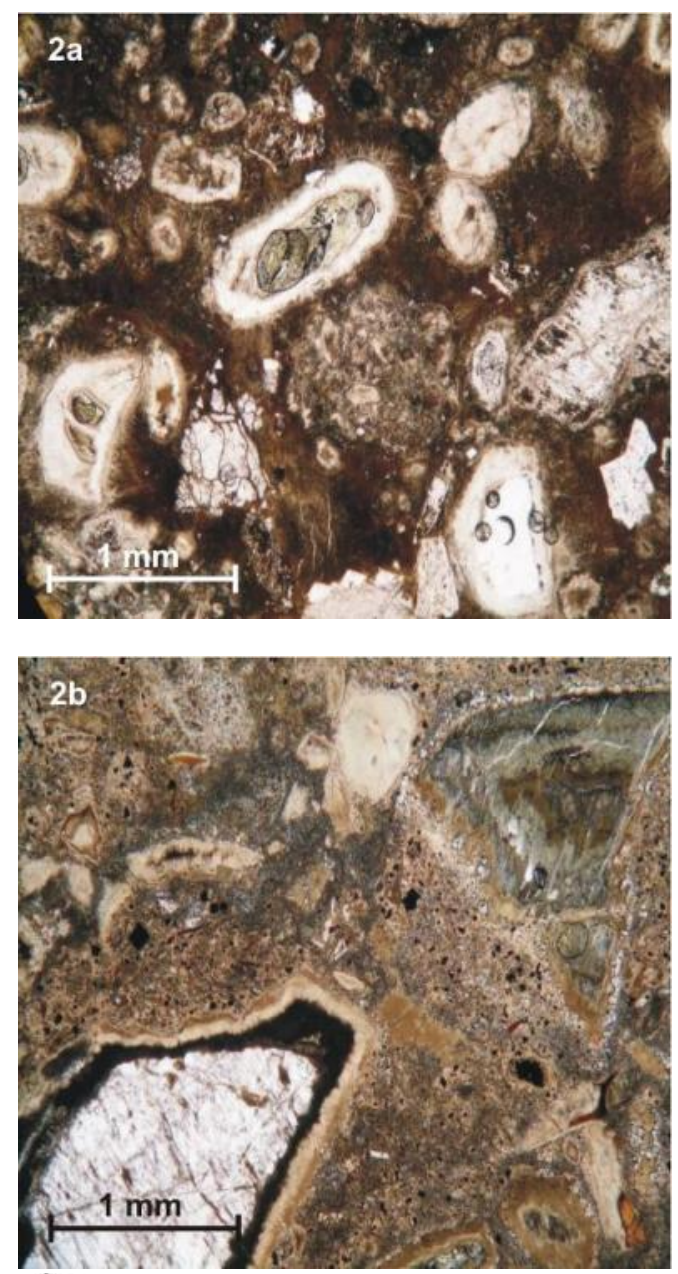
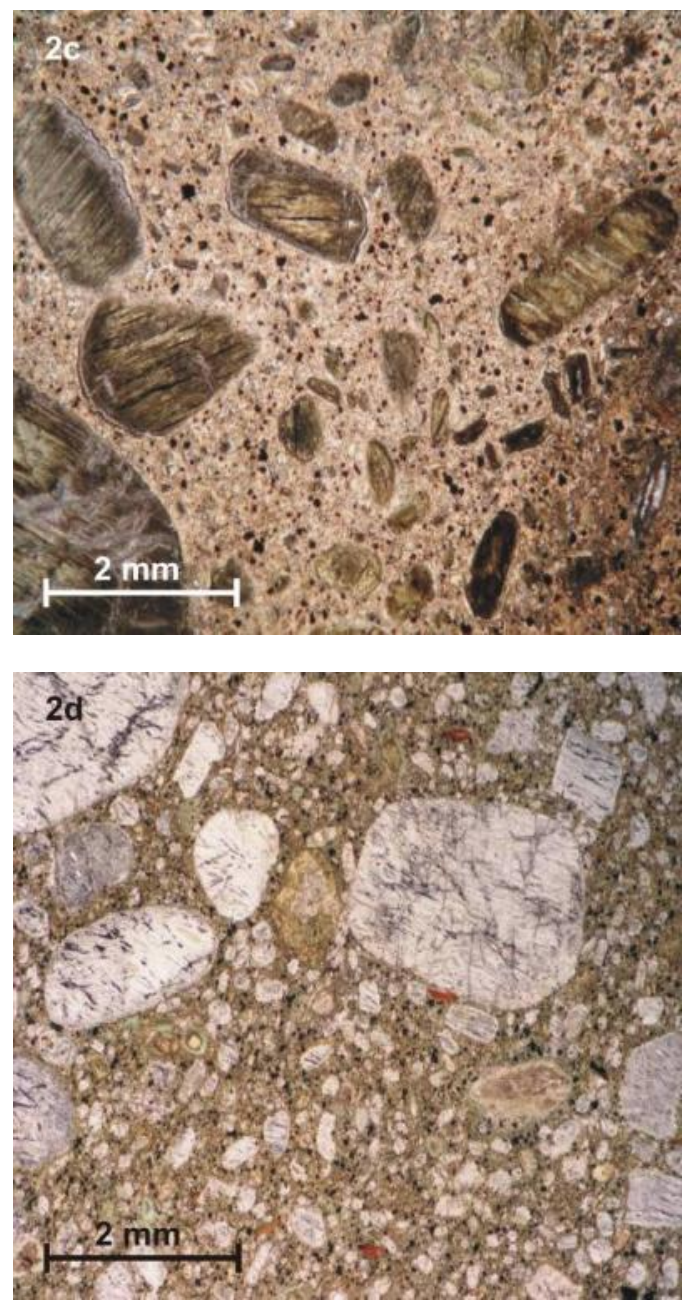

Figure 2: (a) Blue kimberlite characterized by extensively altered olivine macrocrysts and fresh country rock xenoliths. Note the clinopyroxene microlites overprinting the olivines. (b) Brown kimberlite characterized by an inhomogeneous groundmass. (c) An example of a uniform, homogeneous, undiluted Brown kimberlite. (d) Uniform, hypabyssal kimberlite from a late stage dyke.

In comparing the two main phases, the Blue and Brown kimberlites display contrasting textures, xenolith abundances and populations and dissimilar olivine populations. The Brown kimberlite is characterized by a high proportion (20 to $40 \%$ ) of medium to very coarse grained ( $3 \mathrm{~mm}$ to $>10 \mathrm{~mm}$ ) olivine macrocrysts, and the Blue unit is characterized by olivine macrocrysts that are typically smaller ( 3 to $6 \mathrm{~mm}$ ) and of lower total abundance (5 to 20\%). The brown kimberlite contains a higher macrodiamond grade compared to the Blue kimberlite. Contact relationships between the Blue and Brown units are sharp and in places are highlighted by the intrusion of hypabyssal kimberlite dykes, as well as increased proportions of country rock xenoliths.

The hypabyssal kimberlite (Fig. 2d) sheets are late stage intrusions found throughout the body and 
typically occur along contacts between phases of kimberlite, the pipe wall and throughout the marginal breccias. The sheets are characterized by two generations of olivine set within a homogeneous, well crystallized groundmass. The majority of the sheets are less altered than the main pipe infills. Mineralogically the groundmass varies between monticellite and phlogopite dominated varieties. The majority of the sheets are undiluted; however, sheets emplaced within the marginal breccias can contain significant country rock and appear fragmental. Thicknesses range from a few centimetres to one metre. Contacts are often characterized by the flow alignment of elongated minerals and carbonate veining. Larger, irregular intrusions of coherent kimberlite are present within the pipe and these contain common country rock xenoliths. The distribution of the HK sheets and irregular coherent intrusions are difficult to model in three dimensions and have not been incorporated in to the 3D model presented in Fig. 1.

A significant country rock breccia halo surrounds much of the Renard 2 kimberlite. These breccias include units that do not contain any kimberlite to zones that contain up to $5 \%$ juvenile material (excluding sheets) mixed within the matrix supported zones. Kimberlitic constituents when encountered are often found adjacent to the main diatreme zone. The breccias are characterized by angular, clast supported fragments and jig-saw fit textures. The matrix between the larger fragments consists of sand-sized, pulverized granitoid material. Excellent examples of rotated country rock blocks $(25-50 \mathrm{~cm})$ dipping inwards toward the diatreme are present in the underground exposure.

\section{Emplacement History}

On the basis of investigations completed to date, the following emplacement history is proposed for Renard 2: (i) Pre-conditioning of the country rock by ascending magma and associated volatiles, leading to the development of country rock breccias. (ii) Breaching of the surface and consequent explosive degassing of kimberlite magma leading to pipe excavation. During pipe generation, marginal breccias were developed and collapsed into the pipe, indicated by well-developed inward dipping country rock blocks. (iii) Infill of the pipe by the Brown kimberlite. (iv) Excavation of the Brown kimberlite and infilling by the Blue kimberlite. (v) Late stage coherent kimberlite sheets and irregular intrusions are emplaced throughout the kimberlite and marginal breccias. (vi) Postemplacement hydrothermal alteration, particularly within the Blue kimberlite, resulting in significant mineral replacement.

\section{Discussion and Conclusions}

The Renard 2 kimberlite is classified as a Class 1 or Kimberley type body and is considered to have undergone extensive erosion and displays geological features consistent with a lower diatreme setting. The features that support this interpretation include the emplacement age, the present surface expression of the pipe, the low degree of textural modification displayed by the main pipe infills, the extensive marginal breccias that are preserved, the subvertical orientation of the contacts between the main pipe infills and the vertical fabrics present within the volcaniclastic rocks. The Brown kimberlite has been interpreted to have been emplaced first, due to its distribution around the outside of the diatreme and the nature of the cross cutting contacts with the Blue kimberlite. The Blue kimberlite was emplaced following the deposition of the Brown and has cored out a significant volume of Brown material. The Blue is thought to have formed by a much more explosive eruption compared to the Brown due to the high proportion of country rock present throughout this phase. Although the top of the pipe has not been preserved, it appears that that the pipe was being infilled with the Blue as well as excavated the pipe simultaneously. In contrast with the Brown, it appears that this kimberlite was formed by a less explosive event within a cleared diatreme. It is possible that the Brown phase may represent a clastogentic type of deposit and further work is required in order to confirm this. The Brown kimberlite is considered to have the highest diamond carrying capacity of the main pipe infills and contains a higher grade compared to the Blue.

\section{References}

Clement, C.R., 1982. A comparative geological study of some major kimberlite pipes in the northern Cape and Orange Free State. Unpublished Ph.D. thesis, University of Cape Town, South Africa. 431 pp.

Hetman, C.M., 2008. Tuffisitic Kimberlite (TK): A Canadian perspective on a distinctive textural variety of kimberlite, Journal of Volcanology and Geothermal Research (2008), doi:10.1016/j.jvolgeores.2007.12.039

Hetman, C.M., Scott Smith, B.H., Paul, J.L., and Winter, F.W., 2004. Geology of the Gahcho Kue kimberlite pipes, NWT, Canada: root to diatreme transition zones. Lithos, 76, 183-200.

Masun, K. and Scott Smith, B.H., 2006. The Pimenta Bueno Kimberlite Field, Rondonia, Brazil: evidence for tuffisitic kimberlite. Long Abstract for 2006 Kimberlite Emplacement Workshop, September, Saskatoon, Saskatchewan, 5 pp. 